\title{
Case Comment
}

\section{A Better Interpretation of "Special Needs" Doctrine After Edmond and Ferguson}

United States v. Miles, 228 F. Supp. 2d 1130 (E.D. Cal. 2002).

In 2000, Congress enacted the DNA Analysis Backlog Elimination Act, ${ }^{1}$ which requires convicted sex offenders and other felons ${ }^{2}$ to submit DNA samples to the Combined DNA Index System (CODIS), a national database used to identify DNA evidence found at crime scenes. ${ }^{3}$ Two federal district courts have applied the Supreme Court's special needs doctrine to determine whether the collection of samples from felons under the DNA Act violates the Fourth Amendment, with different results. This Comment argues that the debate over the constitutionality of the DNA Act demonstrates that the Supreme Court's most recent interpretation of the special needs doctrine is misguided.

Two recent cases, United States v. Miles ${ }^{4}$ and United States $v$. Reynard, ${ }^{5}$ have reached different conclusions about whether the collection of samples under the DNA Act violates the Fourth Amendment. ${ }^{6}$ The Miles

1. 42 U.S.C. \& 14,135a (2000).

2. The DNA Act also applies to individuals convicted of murder, voluntary manslaughter, kidnapping, robbery, and burglary, among other offenses. See id. $\$ 14,135 \mathrm{a}$ (d).

3. See id. $\$ 14,135 \mathrm{a}(\mathrm{b})$. The CODIS is actually a "distributional database" that coordinates local, state, and national DNA gathering programs, and contains more than 210,000 profiles from twenty-four states and the FBI. U.S. DEP'T OF JUSTICE, THE FBI'S COMBINED DNA INDEX SYSTEM PROGRAM 2 (2000), at http://www.fbi.gov/hq/lab/codis/brochure.pdf.

4. 228 F. Supp. 2 d 1130 (E.D. Cal. 2002).

5. 220 F. Supp. 2d 1142 (S.D. Cal. 2002).

6. Other courts have addressed this question. See, e.g., Roe v. Marcotte, 193 F.3d 72 (2d Cir. 1999); Boling v. Romer, 101 F.3d 1336 (10th Cir. 1996); Rise v. Oregon, 59 F.3d 1556 (9th Cir. 1995); Jones v. Murray, 962 F.2d 302 (4th Cir. 1992); Kruger v. Erickson, 875 F. Supp. 583 (D. Minn. 1995). However, those cases were all decided prior to the Supreme Court's decisions in City of Indianapolis v. Edmond, 531 U.S. 32 (2000), and Ferguson v. City of Charleston, 532 U.S. $67(2001)$, and therefore are not relevant to my analysis of the current state of the special needs 
and Reynard courts agreed that the blood-sample extractions mandated by the Act are warrantless searches lacking probable cause, and therefore would be constitutional only if they fell under the "special needs" exception to the warrant requirement. ${ }^{7}$ This exception holds that the government may conduct a search without a warrant or probable cause "when special needs, beyond the normal need for law enforcement, make the warrant and probable-cause requirement impracticable." Both courts further agreed that the Court's recent decisions in City of Indianapolis $\nu$. Edmond and Ferguson v. City of Charleston ${ }^{10}$ should be the guideposts for special needs inquiry. The courts disagreed only on the outcome of that inquiry: Miles struck down the DNA Act searches, ${ }^{11}$ while Reynard upheld them. ${ }^{12}$

Part I of this Comment summarizes the special needs doctrine as interpreted in Edmond and Ferguson; Part Il offers an alternative approach to the doctrine; and Part III applies that alternative approach to the CODIS, concluding that the constitutionality of the CODIS should be evaluated under the alternative doctrine.

In discussing the DNA Act searches, both the Miles and Reynard courts relied on City of Indianapolis v. Edmond and Ferguson v. City of Charleston. ${ }^{13}$ In Edmond, the Court struck down Indianapolis's highway checkpoint program, under which randomly stopped cars were visually inspected by officers and sniffed by narcotics-detecting dogs. ${ }^{14}$ Unlike highway checkpoints with virtually identical effects upheld in earlier cases, ${ }^{15}$ Indianapolis's program was created for the "primary purpose [of detecting] evidence of ordinary criminal wrongdoing." 16 Thus, the Border

doctrine. Two additional cases on the constitutionality of the DNA Act have been decided since Edmond and Ferguson, but those cases do not discuss either decision. See United States v. Meier, CR No. 97-72 HA, 2002 U.S. Dist. LEXIS 25755 (D. Or. Aug. 6, 2002); Groceman v. United States Dep't of Justice, No. CIV.A.301CV1619G, 2002 WL 1398559 (N.D. Tex. June 26, 2002).

7. See Miles, 228 F. Supp. 2d at 1134; Reynard, 220 F. Supp. 2d at 1165 ; see also Skinner v. Ry. Labor Executives' Ass'n, 489 U.S. 602, 616 (1989) (holding that taking a blood sample is a search under the Fourth Amendment).

8. Griffin v. Wisconsin, 483 U.S. 868, 873 (1987) (internal quotation marks and citation omitted). Importantly, not every special needs search is constitutional. If the exception applies, the court must then balance the nature of the privacy interest, the character of the intrusion, and the nature of the government's concern to determine whether the search is reasonable.

9. 531 U.S. 32 .

10. 532 U.S. 67.

11. 228 F. Supp. $2 d$ at 1141.

12. 220 F. Supp. $2 d$ at 1169 .

13. Miles, 228 F. Supp. 2d at 1135-38; Reynard, 220 F. Supp. 2d at 1165-68.

14. 531 U.S. at 48.

15. Compare id. at 35-36, with Mich. Dep't of State Police v. Sitz, 496 U.S. 444, 447-48 (1990), and United States v. Martinez-Fuerte, 428 U.S. 543, 545-47 (1976).

16. Edmand, 531 U.S. at 41 . 
Patrol could stop cars near the border, ${ }^{17}$ and the police could stop motorists for sobriety checks, ${ }^{18}$ because in both cases the searches were justified by a primary purpose distinct from "general crime control ends," namely, safeguarding the border and removing drunk drivers from the roads. But because Indianapolis had conceded that its program "unquestionably [had] the primary purpose of interdicting illegal narcotics," 19 the program could not be similarly justified.

In Ferguson, Charleston proved that it had learned from Indianapolis's unwise concession in Edmond. Charleston argued that a public hospital's policy of testing pregnant women for cocaine use had the primary non-lawenforcement purpose of protecting the health of mother and child, and therefore fell within the special needs exception. ${ }^{20}$ The Court nevertheless struck down the program, concluding that while the "ultimate goal of the program" may have been to get the women into treatment, the "immediate object of the searches was to generate evidence for law enforcement purposes in order to reach that goal." 21

How did the Court distinguish the "immediate object of the searches" at issue in Ferguson from the warrantless drug-testing programs upheld in earlier cases? Here again, the Court defined the special needs category by considering the primary purpose to which the government intended to put the results of the search. Each of the earlier programs upheld by the Court was justified by a purpose that did not involve arrest and prosecution: protecting the integrity of the front lines in the war on drugs, ${ }^{22}$ gathering reliable data on train accidents caused by substance abuse, ${ }^{23}$ or ensuring the safety of high school students. ${ }^{24}$ The Charleston policy, by contrast, focused on "the arrest and prosecution" of the drug-abusing mothers. ${ }^{25}$

Taken together, Edmond and Ferguson articulate a kind of evidentiary approach to special needs analysis. In determining whether a warrantless search falls under the special needs exception, the court asks, "What is the primary purpose to which the government intends to put the results of the search?" If the answer is simply, "to generate evidence for law enforcement purposes, ${ }^{26}$ then the exception does not apply. If, however, the government

17. Martinez-Fuerte, 428 U.S. 543.

18. Sitz, 496 U.S. 444.

19. Edmond, 531 U.S. at 40 . Because of this concession, the Court "express[ed] no view" on whether an identical checkpoint program justified by "the primary purpose of checking licenses" would be constitutional. Id. at $47 \mathrm{n} .2$.

20. Ferguson v. City of Charleston, 532 U.S. 67, 73 (2001).

21. Id. at 83 .

22. Nat'I Treasury Employees Union v. Von Raab, 489 U.S. 656, 670 (1989).

23. Skinner v. Ry. Labor Executives' Ass'n, 489 U.S. 602, 620-23 (1989).

24. Bd. of Educ. v. Earls, 536 U.S. 822 (2002).

25. Ferguson, 532 U.S. at 82 (citation omitted).

26. Id. at 83 . 
can plausibly argue that it needs the search results primarily for something other than criminal prosecution, then the special needs exception applies.

The Miles and Reynard courts faithfully applied this test in their analyses of the constitutionality of the DNA Act searches. In both cases, the government argued that the primary purpose of the searches was to create a more accurate DNA database, which would assist law enforcement in solving past and future crimes and thereby ensure a more accurate criminal justice system. ${ }^{27}$ The Miles court concluded that this purpose was "indistinguishable from the government's basic interest in enforcing the law," since the evidence was being used to solve and prosecute crimes. ${ }^{28}$ The Reynard court, on the other hand, found that "the creation of a more accurate criminal justice system" was a purpose that went beyond "the normal need for law enforcement." 29

Thus, the debate between the Miles and Reynard courts over the constitutionality of the DNA Act searches amounted to a semantic disagreement over the meaning of "law enforcement purposes." focusing their attention on whether the creation of a more accurate criminal justice system is a "law enforcement purpose," both courts ignored many of the central issues pertaining to the reasonableness of the DNA Act searches.

This definitional quandary, moreover, is inevitable under the special needs test as articulated in Edmond and Ferguson. Those cases frame the special needs inquiry in terms of whether the government's primary purpose in obtaining the results of the search is law-enforcement-related. In applying this test, lower courts faced with special needs arguments will have to determine (1) whether a given purpose is non-law-enforcementrelated, and (2) if so, whether that is the primary purpose of the search.

But there are several reasons why these questions are not helpful in determining whether warrantless searches are reasonable, which is, after all, the point of the special needs exception. First, there is no reason to believe that searches conducted primarily for non-law-enforcement purposes are categorically more likely to be reasonable than law enforcement searches. The Court has noted, "It is surely anomalous to say that the individual and his private property are fully protected by the Fourth Amendment only when the individual is suspected of criminal behavior." 31

27. Miles, 228 F. Supp. 2d at 1138-39; United States v. Reynard, 220 F. Supp. 2d 1142, 1167 (S.D. Cal. 2002).

28. 228 F. Supp. $2 d$ at 1139.

29. 220 F. Supp. $2 d$ at 1168.

30. At the end of its opinion, the Miles court noted, "The only difference between Reynard and the court's decision here is that in Reynard the court concluded that the Act's goals of ensuring accurate prosecution and creating a more complete DNA database were distinct from general law enforcement objectives." 228 F. Supp. 2d at 1141.

31. Camara v. Mun. Court, 387 U.S. 523, 530 (1967) (applying the warrant requirement to municipal housing inspections); see also Michigan v. Tyler, 436 U.S. 499, 504 (1978) ("The decisions of this Court firmly establish that the Fourth Amendment extends beyond the 
Second, the distinction between law enforcement and non-lawenforcement purposes is not entirely clear. Most of the warrantless searches upheld under special needs analysis had a law enforcement purpose in the sense that they ultimately led to an arrest and/or criminal prosecution. ${ }^{32}$ Conversely, nearly any law enforcement search could also be said to have a non-law-enforcement purpose, since "law enforcement involvement always serves some broader social purpose or objective." 33 Thus, most warrantless searches will have both law enforcement and non-law-enforcement purposes. Edmond and Ferguson suggest that a special needs search is one in which the non-law-enforcement purpose is "primary," but offer little guidance about how to distinguish primary from secondary purposes. ${ }^{34}$

Third, the special needs test suggests that subjective intent is relevant to the reasonableness of the search: "[O]ur special needs... cases demonstrate that purpose is often relevant when suspicionless intrusions pursuant to a general scheme are at issue. ${ }^{335}$ But this approach is inconsistent with the Court's holding in Whren v. United States that an actor's motive does not "invalidate[] objectively justifiable behavior under the Fourth Amendment." 36

The special needs doctrine as articulated in Edmond and Ferguson and applied in Miles and Reynard asks an evidentiary question: Does the government have a special (i.e., non-law-enforcement-related) need for the fruits of the search? I propose that the special needs doctrine should instead ask an administrative question: Does the context of the search at issue

paradigmatic entry into a private dwelling by a law enforcement officer in search of the fruits or instrumentalities of crime."); William J. Stuntz, Privacy's Problem and the Law of Criminal Procedure, 93 MiCH. L. REV. 1016, 1017 (1995) ("[M]uch of what the modern state does outside of ordinary criminal investigation intrudes on privacy just as much as the kinds of police conduct that Fourth and Fifth Amendment law forbid.").

32. See, e.g., Mich. Dep't of State Police v. Sitz, 496 U.S. 444 (1990); Griffin v. Wisconsin, 483 U.S. 868 (1987); New Jersey v. T.L.O., 469 U.S. 325 (1985); United States v. MartinezFuerte, 428 U.S. 543 (1976); cf. Camara, 387 U.S. at 530-31 (stating that noncriminal searches frequently have criminal consequences).

33. Ferguson v. City of Charleston, 532 U.S. 67, 84 (2001).

34. D.H. Kaye, The Constitutionality of DNA Sampling on Arrest, 10 CORNELL J.L. \& PUB. POL'Y 455, 496 (2001) ("[N]either Edmond nor Ferguson reaches the more vexing question of what evidence can be used to infer purpose when the government contends that its immediate purpose in instituting an investigative practice is something other than (or in addition to) pure crime control.").

35. City of Indianapolis v. Edmond, 531 U.S. 32, 47 (2000).

36. 517 U.S. 806, 812 (1996); see also Edmond, 531 U.S. at 52 (Rehnquist, C.J., dissenting) ("Once the constitutional requirements for a particular seizure are satisfied, the subjective expectations of those responsible for it, be it police officers or members of a city council, are irrelevant."); George M. Dery III, A Deadly Cure: The Supreme Court's Dangerous Medicine in Ferguson v. City of Charleston, 55 OKLA. L. REV. 373, 410 (2002). 
create a special need for warrantless searches? When the government conducts business-as-usual crime fighting, the Fourth Amendment requires that searches and seizures be based on individualized suspicion. ${ }^{37}$ But when the context of the search differs from everyday police work, the government may be able to articulate a special need for warrantless searches, even if its primary purpose in obtaining that evidence is prosecutorial.

Thus, school searches fall within the special needs exception because the warrant requirement is unsuited to the school environment. Requiring teachers, who are not familiar with Fourth Amendment jurisprudence, to obtain a warrant before searching a student "would unduly interfere with the maintenance of the swift and informal disciplinary procedures needed in the schools." ${ }^{38}$ Similarly, warrantless stops near the border are permissible on the ground that a warrant requirement "would be impractical because the flow of traffic tends to be too heavy to allow the particularized study of a given car. ${ }^{39}$ Likewise, suspicionless drug testing of railroad employees immediately after an accident is necessary because the delay required to obtain a warrant would destroy much of the toxicological evidence the government needs to determine whether the accident was drug- or alcoholrelated-again, an administrative consideration. ${ }^{40}$ And so on.

The administrative interpretation of the special needs doctrine suggests that the Edmond highway checkpoint program was unconstitutional because, with the narrow exception of border searches, ${ }^{41}$ highway checkpoints cannot be justified by an administrative special need. Drug couriers are the targets of everyday law enforcement. Their illegal activities are supposed to make them susceptible to apprehension through ordinary law enforcement methods. The suspicionless searches at the highway checkpoints were simply a shortcut around these methods.

The key fact in Ferguson was that law enforcement and city prosecutors were involved in the hospital's drug-testing program from its inception-deciding who would be tested, how and when the tests would be conducted, and even establishing a chain of custody for the evidence. ${ }^{42}$ Unlike the drug tests of railroad employees (upheld in Skinner) or high

37. See Mincey v. Arizona, 437 U.S. 385, 393 (1978) ("[T] may be made more efficient can never by itself justify disregard of the Fourth Amendment.").

38. New Jersey v. T.L.O., 469 U.S. 325,340 (1985).

39. United States v. Martinez-Fuerte, 428 U.S. 543, 557 (1976).

40. Skinner v. Ry. Labor Executives' Ass'n, 489 U.S. 602, 623 (1989).

41. Border searches are necessary "because of national self protection reasonably requiring one entering the country to identify himself as entitled to come in, and his belongings as effects which may be lawfully brought in." Carroll v. United States, 267 U.S. 132, 154 (1925). The heavy flow of traffic at the border makes a random search regime the only way to administer such searches. But this administrative need does not extend to highway checkpoints outside the border search context. See Edmond, 531 U.S. at 56 (Thomas, J., dissenting) ("I rather doubt that the Framers of the Fourth Amendment would have considered 'reasonable' a program of indiscriminate stops of individuals not suspected of wrongdoing.").

42. Ferguson v. City of Charleston, 532 U.S. 67, 82 (2001). 
school students (upheld in Earls), the drug tests in Ferguson were not administered by officials unfamiliar with Fourth Amendment jurisprudence. Nor was there any danger, as in Skinner, that evidence would be lost because of the delay necessary to obtain a warrant, since the women were in the hospital for an extended period to give birth. The involvement of police and prosecutors in the administration of the program has constitutional significance, not because it reveals a primary law enforcement purpose, but rather because it suggests that, as in Edmond, the warrantless search program was nothing more than a police shortcut.

This brief account of the Court's recent cases suggests that, under the administrative interpretation, the special needs doctrine would likely apply when (1) the search is administered by non-law-enforcement officials; (2) the delay necessary to obtain a warrant would result in the loss of evidence or otherwise frustrate the purpose of the search; or (3) the context in which the search is conducted necessarily requires randomness, for example because of the sheer number of searches involved. ${ }^{43}$

Does the context of the searches conducted pursuant to the DNA Act create a need for a warrantless regime of searches? The benefit to innocent persons of an accurate DNA database suggests that the answer is yes.

One reason suspicionless searches are disfavored under the Fourth Amendment is the burden such searches place on innocent persons. ${ }^{44}$ Under a suspicionless search regime, innocent persons are inconvenienced and intruded upon in a way they would not be if the government were required to obtain a warrant based on individualized suspicion of wrongdoing. Consequently, if a suspicionless search regime has important collateral benefits to innocent persons (beyond the generalized benefit of better law enforcement, which would exist in any search regime), those consequences are a good argument in favor of the constitutionality of the searches.

The Miles court quickly dismissed the benefit to innocent persons of an accurate DNA database, noting that "[i]f a convicted felon wants to be exonerated of a crime for which he is wrongly accused, he will presumably submit voluntarily to a DNA test." ${ }^{\text {"S }}$ But the court ignored the important benefit to a wrongly accused person of a database that would eliminate him as a suspect, not by ruling him out, but by incriminating someone else. For example, if two or more individuals commit a crime, but only one leaves

43. This list is meant to be illustrative (rather than exhaustive) of the kinds of administrative reasons that would justify a special needs exception.

44. See Amold H. Loewy, The Fourth Amendment as a Device for Protecting the Innocent, 81 MICH. L. REV. 1229 (1983).

45. Miles, 228 F. Supp. $2 d$ at 1139 
DNA evidence at the crime scene, the fact that my DNA does not match the evidence does not eliminate me as a suspect. But if that evidence, through the CODIS, incriminates another person whom I have never met and to whom I have no connection, I have received an important collateral benefit from the suspicionless search regime necessary to implement the CODIS. ${ }^{46}$

The point here is that whether or not the maintenance of a DNA database for the purpose of exonerating innocent persons is properly characterized as law-enforcement-related, that benefit simply cannot be achieved without a regime of warrantless searches. If the government had to obtain a warrant before conducting DNA Act searches, the CODIS database would likely fail. The government would not be able to establish probable cause for the vast majority of the searches, and would not go to the trouble of getting so many warrants even if it could. The warrantless searches mandated by the DNA Act are not merely law enforcement shortcuts. Rather, they are a necessary precondition to the maintenance of a DNA database, which has an important value to innocent persons. Therefore, the administrative interpretation suggests that the DNA Act searches should be evaluated under the special needs exception to the warrant requirement.

There are, to be sure, important arguments against the constitutionality of the CODIS. First, given the massive amounts of information about an individual that can be revealed through DNA analysis, the extraction of a DNA sample can be an extraordinarily intrusive search. If a searchee could show that the Act's disclosure limitation requirements were insufficient or ineffectively implemented, a court might conclude that the burden of the search outweighed the benefits. Second, the burdens and benefits of the suspicionless searches at issue here are disproportionately distributed. The burdens of the DNA Act searches are most likely to fall on convicted criminals, a politically powerless group, while the beneficiaries are the members of society at large. These considerations, though, seem most relevant at the second stage of the special needs inquiry-the balancing of the privacy interests at stake against the nature of the government's concern. My point here is not to establish the constitutionality of the DNA Act, but rather to argue that my proposed interpretation of the special needs doctrine suggests that the Act should be evaluated under that doctrine. The DNA Act does fall within the special needs exception, not because its primary purpose, immediate need, or ultimate objective is non-lawenforcement-related, but because in the context of the searches at issue, the government has important administrative reasons for needing a warrantless regime of searches.

- Jonathan Kravis

46. See Akhil Reed Amar, A Search for Justice in Our Genes, N.Y. TIMES, May 7, 2002, at A31. 